\title{
Performance characteristic of C-130E Hercules aircraft engine under variable work conditions
}

\begin{abstract}
The paper describes the basic components and the principle of operation of a turboprop engine of the C-130 Hercules aircraft. The paper also includes an extensive analysis of the aircraft flight profile (departing from the Powidz airfield, Poland to Bagram Afghanistan). Following the flight log, the paper contains many calculations, to show the influence of the changing meteorological conditions on the aircraft performance, particularly temperature, altitude and ambient pressure. The results of the investigation constitute the foundations to create further steps of the research for the optimization of a flight profile that balances the amount of fuel and mass of the cargo. Finally, the authors suggest a development of specific software to simulate a flight prior to departure, based upon available data before the mission.
\end{abstract}

Key words: aircraft engine, variable work conditions

\section{Charakterystyka pracy silnika samolotu C-130E Hercules w zmiennych warunkach pracy}

\begin{abstract}
W pracy przedstawiono podstawową budowę i zasadę działania silnika samolotu C-130 Hercules jak również analizę uproszczonego profilu lotu z lotniska w Powidzu do Bagram (Afganistan). Zrealizowano zbiór obliczeń dla poszczególnych etapów lotu w celu przedstawienia wptywu zmiennych warunków atmosferycznych na osiagi samolotu, ze szczególnym uwzględnieniem temperatury i ciśnienia atmosferycznego. Wysunięto wnioski stanowiace podstawę do nakreślenia kolejnych kierunków badań w celu optymalizacji profilu lotu dla odpowiedniej ilości paliwa oraz załadunku. Ostatecznie autorzy, na podstawie syntezy wyników badań, wnioskuja o opracowanie programu komputerowego dla dokonywania symulacji lotu przed jego wykonaniem, posiadając dane dostępne przed każda misją.
\end{abstract}

Słowa kluczowe: silnik lotniczy, zmienne warunki pracy

\section{Introduction}

The aim of this study is the analysis of the variable parameters that influence the aircraft performance during a long distance cruise from Poland to Afghanistan (fuel count and cargo included). In order to solve the research problem the paper analyzes the flight profile consisting of takeoff, climb to a cruising altitude, steady flight at a set altitude, descent, landing and taxi under variable atmospheric conditions for average temperatures in the summer and wintertime for the airfields of Powidz and Bagram (Afganistan).

\section{The design and principle of operation of the $\mathbf{C}-\mathbf{1 3 0}$ Hercules engine}

The biggest asset in the Polish air force in terms of dimensions and cargo capacity has for some time now been a highly experienced, well-tested aircraft known as Lockheed C-130 Hercules. C-130 is a modern four engine medium sized transport aircraft of an extremely wide range of possible applications in the military and civilian aviation. The aircraft is fitted in four turboprop T56-A-7 engines of the power output $3162 \mathrm{~kW}(4300 \mathrm{KM})$ each [1]. The basic engine elements are as follows (Fig. 1): compressor intake, 14 stage axial compressor, 6 combustors, 4 -stage turbine mechanically connected with the compressor rotor and the propeller reduction gearset (13.54 reduction ratio between the engine speed and the propeller speed). The reduction gearset of the propeller is composed of two reduction stages, enabling a reduction of the engine turbine shaft speed from

\section{Wprowadzenie}

Celem pracy jest analiza zmiennych czynników wpływających na osiągi samolotu C-130 wykonującego lot długodystansowy z Polski do Afganistanu, z uwzględnieniem kalkulacji ilości paliwa oraz towaru transportowanego do miejsca przeznaczenia. Dla rozwiązania problemu badawczego w artykule przeanalizowano profil lotu składający się ze startu, wznoszenia na określoną wysokość, lot poziomy, zniżania oraz lądowania i dobiegu w zmiennych warunkach atmosferycznych dla średnich temperatur zimą i latem dla lotnisk Powidz oraz Bagram (Afganistan).

\section{Budowa i zasada pracy silnika samolotu C-130 Hercules}

Największy nabytek pod względem rozmiarów przestrzennych i udźwigu ostatnich lat w Siłach Powietrznych RP stanowi sprawdzona konstrukcja o bogatym doświadczeniu, samolot Lockheed C-130 Hercules. Samolot C-130 to czterosilnikowy średni transportowiec o bardzo szerokim obszarze zastosowania w lotnictwie wojskowym i cywilnym. Samolot jest wyposażony w cztery silniki turbośmigłowe typu T56-A-7 o znamionowej mocy $3162 \mathrm{~kW}$ (4300 KM) każdy [1]. Do podstawowych elementów składowych silnika (rys. 1) zalicza się: wlot do sprężarki, 14 stopniową sprężarkę osiową, 6 komór spalania, 4 stopniową turbinę sprzężoną mechanicznie z wirnikiem sprężarki i przekładnią redukcyjną śmigła (o redukcji 13,54 pomiędzy prędkością obrotową silnika a prędkością obrotową śmigła). Przekład- 


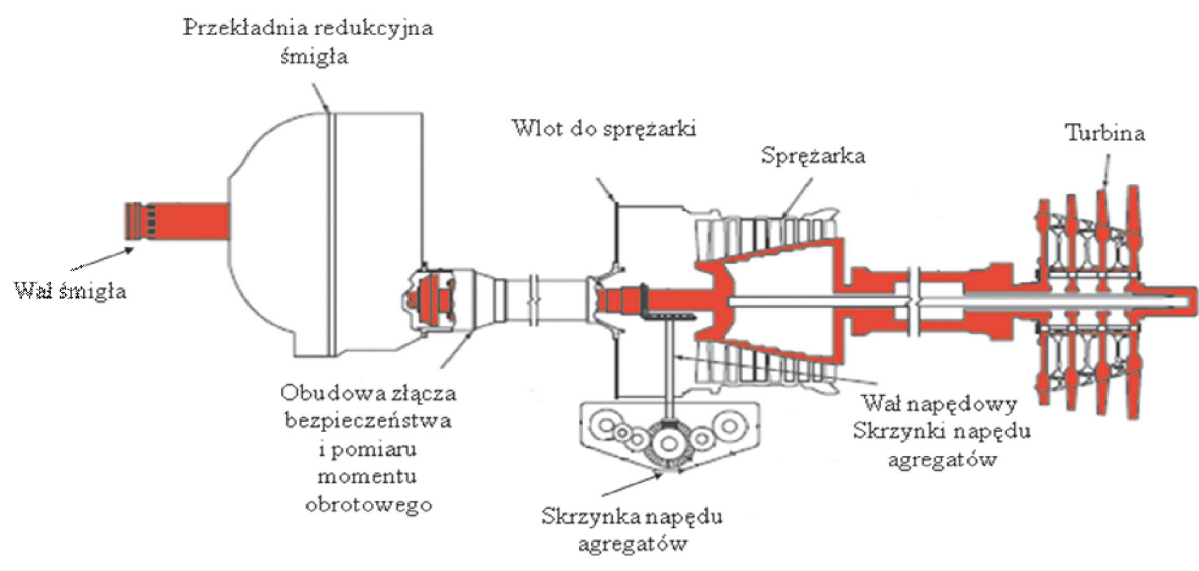

Fig. 1. Basic T56-A-7 engine components [1]

Rys. 1. Podstawowe elementy sktadowe silnika T56-A-7 [1] nia redukcyjna śmigła składa się z dwóch stopni redukcji, dzięki czemu możliwe jest zmniejszenie prędkości obrotowej wału turbiny silnika od wartości $13820 \mathrm{obr} / \mathrm{min}$ do 1021 obr/min. Prędkość ta, ze względu na konieczność kontroli pracy zespołu śmigło-silnik, umownie określana jest jako $100 \%$ obrotów na minutę.

Podstawową właściwością powyższego silnika jest to, że moc nie jest adekwatna do prędkości obrotowej wału turbiny, lecz odpowiada temperaturze gazów na wlocie do niej (TIT - ang. Turbine Inlet Temperatu-

$13820 \mathrm{rpm}$ to $1021 \mathrm{rpm}$. This speed value, for the sake of control of the operation of the engine-propeller assembly, is known as $100 \%$ revolutions per minute.

The basic feature of this engine is that its power is not adequate to the speed of the turbine shaft, but corresponds to the temperature of the gases at the intake (TIT - Turbine Inlet Temperature). During the flight, the propeller maintains a steady speed, which is an indicator determined as the optimum power and efficiency. The change of the setting on the power lever changes the propeller geometry (AOA). In order to maintain steady propeller speed, the fuel system automatically supplies an appropriate fuel dose into the combustor, the result of which is increase or decrease in the TIT, hence a growth or drop in the gas energy flowing through the turbine. The change of the power lever setting does not directly influence the propeller geometry but only reduces or increases the fuel dosage into the combustor. The increase in the temperature in the combustor results in the growth of the power and torque of the propeller. Under such circumstances the propeller management system increases the angle of attack of the propeller blades in order to absorb the generated torque.

The values of the ambient temperature and pressure at the engine intake define their density and for a steady propeller speed (steady states of operation) they determine the power for a set gas temperature TIT (fuel stream). The stream of the air mass (given in pounds per second) entering the engine is the main factor influencing the torque generated for the TIT set by the pilot (temperature of the intake gases at the engine turbine). If the pressure at the intake is steady and the ambient air temperature is reduced, the engine power will grow, which is a result of the increase in the density of the intake air. This can be noticed at the aircraft takeoff on a cold day, when the torquemeter has to be carefully watched in order to avoid exceeding the maximum parameters as opposed to a warmer day (higher ambient temperature) $)^{1)}$.

1) At the same parameters TIT on a day of higher temperature the torque will be proportionally lower. re). Podczas lotu śmigło utrzymuje stałą prędkość obrotową, która jest wskaźnikiem określonym jako optymalna moc i wydajność silnika. Zmiana ustawienia dźwigni sterowania mocą silników w zakresie „Ziemia gaz” powoduje zwiększenie lub zmniejszenie kąta natarcia śmigła. W celu utrzymania stałej prędkości obrotowej śmigła, układ paliwowy automatycznie dozuje odpowiednią dawkę paliwa do komory spalania silnika, w wyniku czego następuje wzrost lub spadek TIT a co za tym idzie zwiększenie lub zmniejszenie energii spalin przepływających przez turbinę. W zakresie ustawienia dźwigni sterowania silnika od „Lotny gaz” do „Maksymalnego”, zmiana ustawienia dźwigni sterowania silnikami nie wpływa bezpośrednio na zmianę kąta ustawienia śmigieł a jedynie na zwiększenie lub zmniejszenie ilości paliwa dostarczanej do komory spalania. Wzrost temperatury w komorze spalania powoduje zwiększenie mocy silnika i momentu obrotowego śmigieł. W tej sytuacji system zarządzania sterowaniem śmigłami zwiększa kąt natarcia łopat w celu absorbowania powstałego momentu.

Wartości temperatury i ciśnienia otaczającego powietrza w obszarze wlotu do silnika decydują o jego gęstości, a dla stałej prędkości obrotowej śmigła (stałych warunków pracy) określa moc dla zadanej temperatury gazów TIT (strumienia paliwa). Strumień masy powietrza (określony w funtach na sekundę) wpływającego do silnika jest głównym czynnikiem wpływającym na moment obrotowy generowany dla określonej przez pilota wielkości TIT (temperaturze gazów wlotowych na turbinę silnika). Jeżeli utrzymuje się stałe ciśnienie powietrza na wlocie do silnika a temperatura zewnętrznego powietrza zmniejszy się, moc silnika wzrośnie, co jest wynikiem wzrostu gęstości wpływającego powietrza. Fakt ten jest zauważalny przy starcie samolotu w chłodny dzień, gdzie wskaźnik momentomierza w kabinie załogi musi być uważnie obserwowany, aby uniknąć sytuacji, w której parametry pracy silnika mogą być przekroczone w porównaniu do dnia, w którym temperatura otaczająca jest wyższa ${ }^{1)}$.

1) Przy tych samych parametrach TIT w dzień o wyższej temperaturze moment obrotowy będzie odpowiednio mniejszy. 


\section{The analysis of the flight profile of $\mathrm{C}-130 \mathrm{E}$ on a flight from Poland to Afghanistan}

The transport aircraft, because of its original purpose (mainly related to long distance transportation of people or cargo) operates in environments of variable characteristics not only related to the atmospheric conditions, but also operating conditions such as flying through the theater of war operations. Thus, it results that the basic problem of an aircraft engine is its operation under changing conditions and their influence on the engine characteristics for the obtainment of the maximum efficiency. In order to describe the operation of the C-130E engine the flight profile was analyzed under variable conditions for average temperatures in the summer and wintertime for the airfields of Powidz and Bagram. The average temperature for the Bagram airfield (located at the elevation of $4265 \mathrm{ft}$ (1300

\section{Analiza profilu lotu samolotu C-130E z Polski do Afganistanu}

Samolot transportowy $\mathrm{z}$ uwagi na swoje podstawowe przeznaczenie, głównie związane z przewozem ludzi lub towaru na długich trasach, prowadzi operacje $\mathrm{w}$ środowisku o zróżnicowanej charakterystyce nie tylko związanej z warunkami atmosferycznymi, ale również i operacyjnymi, takimi jak strefa działań wojennych. $\mathrm{Z}$ tego wynika, że podstawowym problemem silnika lotniczego jest jego praca w zmieniającym się otoczeniu i jej wpływ na jego charakterystykę dla uzyskania optymalnej wydajności. W celu opisania pracy silnika samolotu C-130E przeanalizowano profil lotu w zmiennych warunkach atmosferycznych dla średnich temperatur zimą i latem, dla lotnisk Powidz oraz Bagram. Średnia temperatura dla lotniska Bagram poło-

Table 1. Calculated torque of the C-130E propeller - engine assembly for the airfields of Powidz and Bagram and for different operating conditions [7]

Tabela 1. Obliczony moment obrotowy zespołu śmigło-silnik samolotu C-130E dla lotnisk Powidz oraz Bagram oraz różnych warunków pracy [7]

\begin{tabular}{|c|c|c|}
\hline Ambient conditions/uwarunkowania & Powidz & Bagram \\
\hline Temperature/temperatura & $20^{\circ} \mathrm{C}$ & $38^{\circ} \mathrm{C}$ \\
\hline Airfield elevation/wysokość lotniska & $381 \mathrm{ft}(116 \mathrm{~m})^{5}$ & $4265 \mathrm{ft}(1300 \mathrm{~m})$ \\
\hline Assumed TIT for takeoff/zatożone TIT do startu & $932^{\circ} \mathrm{C}($ maximum continuous $)$ & - \\
\hline Calculated torque/obliczony moment obrotowy & $13500 \mathrm{lb} /$ in $(1525 \mathrm{~N} \cdot \mathrm{m})^{6)}$ & $11750 \mathrm{lb} / \mathrm{in}(1327 \mathrm{~N} \cdot \mathrm{m})$ \\
\hline
\end{tabular}

m) [2]) in the summertime falls within the range of $16^{\circ} \mathrm{C}$ to $38^{\circ} \mathrm{C}$ [3], and in the wintertime is approximately $0^{\circ} \mathrm{C}^{2)}$. For the Powidz airfield located at the elevation of $381 \mathrm{ft}(116 \mathrm{~m})$ [4] the average winter temperature falls within the range of $-6^{\circ} \mathrm{C}$ to $0^{\circ} \mathrm{C}$ and in the summer time $16.5^{\circ} \mathrm{C}$ to $20^{\circ} \mathrm{C}$ [5].

The first comparison was done taking into account the power expressed through the torque for $95 \%{ }^{3)}$ of the engine efficiency. The authors assumed that in the summertime, when accelerating for takeoff, the plane reached the speed of $80 \mathrm{KCAS}^{4}$ ) (calibrated flight velocity- $148 \mathrm{~km} / \mathrm{h}$ ) in the airfield in Powidz and Bagram and proper torque values were obtained (table 1).

From the above calculations it results that the difference in the torque amounts to $1750 \mathrm{lb} / \mathrm{in}(198 \mathrm{~N} \cdot \mathrm{m})$ and if we additionally compare the fuel consumption of the aircraft this parameter will be as follows for the following airfields:

- Powidz - $3338 \mathrm{~kg} / \mathrm{h}$ of the engine operation (7360 pounds/h),

- Bagram - $2722 \mathrm{~kg} / \mathrm{h}$ of the engine operation $(6000$ pounds/h)

The here presented values show how important the airfield elevation is for the operating parameters of the

\footnotetext{
${ }^{2)}$ In the paper extreme temperatures were assumed to stress the possible adverse conditions of the engine operation

3) Due to the safety margin and possible calculation errors, all the characteristics were created with a $5 \%$ safety margin

4) Calibrated Flight Velocity

5) $1 \mathrm{ft}=0.305 \mathrm{~m}$

6) $1 \mathrm{~N} \cdot \mathrm{m}=8.85075 \mathrm{lb} /$ in
}

żonego na wysokości $4265 \mathrm{ft}$ (1300 m) [2], latem zawiera się w granicach od $16^{\circ} \mathrm{C}$ do $38^{\circ} \mathrm{C}$ [3], natomiast w okresie zimowym wynosi około $0^{\circ} \mathrm{C}^{2)}$, natomiast dla lotniska w Powidzu położonego na wysokości $381 \mathrm{ft}(116 \mathrm{~m})$ [4] średnia „zimowa” temperatura mieści się w granicach $-6^{\circ} \mathrm{C}$ do $0^{\circ} \mathrm{C}$ a w okresie letnim $16,5^{\circ} \mathrm{C}$ do $20^{\circ} \mathrm{C}$ [5].

Pierwsze porównanie opracowano $\mathrm{z}$ uwzględnieniem mocy wyrażonej momentem obrotowym dla $95 \%{ }^{33}$ wydajności silnika. Założono, że w okresie letnim podczas rozbiegu samolot osiągnął prędkość $80 \mathrm{KCAS}^{4}$ (kalibrowana prędkość lotu - 148 km/h) na lotnisku w Powidzu i w Bagram, dzięki czemu uzyskano odpowiednie wartości momentu obrotowego (tablica 1).

Z powyższych obliczeń wynika, że różnica momentu obrotowego wynosi $1750 \mathrm{lb} /$ in $(198 \mathrm{~N} \cdot \mathrm{m})$, a jeśli porówna się dodatkowo ile wyniesie zużycie paliwa przez samolot, wówczas parametr ten wyniesie dla lotniska:

- Powidz - $3338 \mathrm{~kg} / \mathrm{h}$ pracy silników (7360 funtów/h), - Bagram - $2722 \mathrm{~kg} / \mathrm{h}$ pracy silników (6000 funtów/h).

Przedstawione wartości liczbowe obrazują jak duże znaczenie ma wysokość położenia lotniska startu na parametry pracy zespołu śmigło-silnik. Startujący samolot z

\footnotetext{
2) $\mathrm{W}$ artykule przyjęto skrajne temperatury dla uwypuklenia możliwych niekorzystnych warunków pracy silnika

3) Z uwagi na margines bezpieczeństwa i możliwe błędy obliczeniowe, wszystkie charakterystyki opracowano z 5\% marginesem bezpieczeństwa

4) Kalibrowana Prędkość Lotu

5) $1 \mathrm{ft}=0,305 \mathrm{~m}$

6) $1 \mathrm{~N} \cdot \mathrm{m}=8,85075 \mathrm{lb} / \mathrm{in}$
} 
propeller-engine assembly. An aircraft taking off from an airfield located at elevations higher by $3904 \mathrm{ft}$ (1189 m) and temperature higher by $18^{\circ} \mathrm{C}$, has a $12.97 \%$ lower value of the torque on the four engines as compared to a lower located airfield. The advantage is lower hourly fuel consumption, yet due to the fact that the takeoff process is very short it is negligible in comparison to the necessity of extending the takeoff distance in order to reach the desired speed at an exactly determined takeoff mass of the aircraft.

While discussing the original purpose of a transport aircraft - carrying of cargo we should determine what the distance would be to reach the takeoff speed. In the situa- lotniska położonego na wyższej wysokości o 3904 ft (1189 m) i temperaturze większej o $18^{\circ} \mathrm{C}$, ma o $12,97 \%$ mniejszą wartość momentu obrotowego na czterech silnikach niż dla niżej położonego lotniska. Korzyścią jest mniejsze godzinowe zużycie paliwa, jednakże z uwagi na kilkusekundowy proces startu nie ma to większego znaczenia w porównaniu z koniecznością wydłużenia drogi startowej do osiągnięcia żądanej prędkości do startu przy ściśle określonej masie statku powietrznego.

Nawiązując do podstawowego przeznaczenia samolotu transportowego, czyli przewożenia towaru, przeanalizować należy jak długą drogę przebędzie samolot, aby uzyskać

Table 2. Calculated distance for the aircraft takeoff at TIT $932^{\circ} \mathrm{C}$ [7]

Tabela 2. Obliczona droga do startu samolotu C-130E przy TIT równym $932^{\circ} \mathrm{C}$ [7]

\begin{tabular}{|c|c|c|}
\hline Ambient conditions/uwarunkowania & Powidz & Bagram \\
\hline Ambient temperature/temperatura otoczenia & $20^{\circ} \mathrm{C}$ & $381 \mathrm{ft}(116 \mathrm{~m})$ \\
\hline Airfield elevation/wysokość lotniska & $4265 \mathrm{ft}(1300 \mathrm{~m})$ \\
\hline Assumed TIT for take off/założone TIT do startu & $932^{\circ} \mathrm{C}$ (maximum continuous) \\
\hline Without wind, dry runway/bez oddzialywania wiatru i na suchej nawierzchni & $5150 \mathrm{ft}(1569 \mathrm{~m})$ & $9100 \mathrm{ft}(2773 \mathrm{~m})$ \\
\hline Calculated takeoff distance/obliczona droga do startu & & 5 \\
\hline
\end{tabular}

tion under consideration extremely adverse conditions have been taken into account in the summertime in the airfields of Powidz and Bagram. The aircraft mass including the cargo is 155000 pounds $(70306 \mathrm{~kg})^{7)}$ being the maximum takeoff mass for that plane.

From table 2 it results that the plane taking off from the Bagram airfield has a takeoff distance longer by 3950 $\mathrm{ft}(1203 \mathrm{~m})$ as compared to the Powidz airfield, which constitutes a value higher by approximately $76 \%$. In such a situation the crew can increase the power and reduce the distance needed for takeoff by increasing TIT up to the value of $977^{\circ} \mathrm{C}$ (Maximum Take-Off Power) by $45^{\circ} \mathrm{C}$ for each engine. prędkość oderwania się od ziemi (ang. Take-Off Speed). W rozważanej sytuacji wzięto pod uwagę również skrajnie niekorzystne warunki w okresie letnim na lotniskach w Powidzu i w Bagram. Masa samolotu wraz z towarem to 155000 funtów $(70306 \mathrm{~kg})^{7)}$ stanowiąca maksymalną masę do startu.

Z tablicy 2 wynika, że samolot startujący z lotniska w Bagram potrzebuje dłuższą drogę startową o $3950 \mathrm{ft}$ (1203 m) niż gdyby startował z lotniska w Powidzu, co stanowi wartość większą o około $76 \%$. W tej sytuacji załoga może zwiększyć potrzebną moc i tym samym skrócić drogę potrzebną na start, zwiększając TIT do wartości $977^{\circ} \mathrm{C}$ (ang. Maximum Take-Off Power) o $45^{\circ} \mathrm{C}$ dla każdego silnika.

Table 3. Calculated takeoff distance for C-130E at TIT $977^{\circ} \mathrm{C}$ [7]

Tabela 3. Obliczona droga do startu samolotu C-130E przy TIT równym $977^{\circ} \mathrm{C}$ [7]

\begin{tabular}{|c|c|c|}
\hline Ambient conditions/uwarunkowania & Powidz & Bagram \\
\hline Ambient temperature/temperatura otoczenia & $20^{\circ} \mathrm{C}$ & $38^{\circ} \mathrm{C}$ \\
\hline Airfield elevation/wysokość lotniska & $381 \mathrm{ft}(116 \mathrm{~m})$ & $4265 \mathrm{ft}(1300 \mathrm{~m})$ \\
\hline Assumed TIT for takeoff/założone TIT do startu & $977^{\circ} \mathrm{C}$ (maximum take-off power) \\
\hline Without wind, dry runway/bez oddziatywania wiatru i na suchej nawierzchni & $4300 \mathrm{ft}(1310 \mathrm{~m})$ & $7800 \mathrm{ft}(2377 \mathrm{~m})$ \\
\hline
\end{tabular}


From the above comparisons it results that an increase in the temperature by $45^{\circ} \mathrm{C}$, i.e. $4.8 \%$ in each engine reduced the takeoff distance by $850 \mathrm{ft}(259 \mathrm{~m})$ in the case of Powidz, i.e. $16.5 \%$ and by $1300 \mathrm{ft}(396 \mathrm{~m})$ in the case of Bagram (14.28\%).

Another stage of the analysis of the T56-A-7 engine operation was the time and distance needed for reaching the cruising altitude in order to safely negotiate the terrain obstacles. The above condition does not constitute a problem in Poland but is a serious limitation in fulfillment of the Polish contingent in Afghanistan. The highest peaks in
Z powyższych porównań wynika, że zwiększenie temperatury o $45^{\circ} \mathrm{C}$, czyli o $4,8 \%$ na każdym silniku spowodowało zmniejszenie potrzebnej drogi do startu w przypadku Powidza o $850 \mathrm{ft}$ (259 m), czyli o 16,5\% oraz o $1300 \mathrm{ft}$ (396 m) dla lotniska Bagram (14,28\%).

Kolejnym etapem analizy pracy silnika T56-A-7 był czas oraz droga potrzebna do wejścia na określoną wysokość (poziom lotu), aby bezpiecznie pokonać przeszkody terenowe. Powyższy warunek nie stanowi większego problemu w Polsce, ale jest poważnym ograniczeniem podczas wykonywania operacji lotniczych w ramach Polskiego Kontyngentu

Table 4. Time and distance needed for C-130E to reach the altitude of $20000 \mathrm{ft}(6096 \mathrm{~m})$ [7]

Tabela 4. Droga i czas potrzebny do osiagnięcia przez samolot C-130E wysokości $20000 \mathrm{ft}$ (6096 m) [7]

\begin{tabular}{|c|c|c|c|c|}
\hline Ambient conditions/uwarunkowania & \multicolumn{2}{|c|}{ Bagram (winter/zima) } & \multicolumn{2}{|c|}{ Bagram (summer/lato) } \\
\hline Ambient temperature/temperatura otoczenia & \multicolumn{2}{|c|}{$0^{\circ} \mathrm{C}$} & \multicolumn{2}{|c|}{$38^{\circ} \mathrm{C}$} \\
\hline Airfield elevation/wysokość lotniska & \multicolumn{4}{|c|}{$4265 \mathrm{ft}(1300 \mathrm{~m})$} \\
\hline Takeoff mass/masa do startu & \multicolumn{4}{|c|}{120000 pounds $(54431 \mathrm{~kg})$} \\
\hline $\begin{array}{l}\text { Assumed TIT for takeoff and climb/ } \\
\text { założone TIT do startu i wznoszenia }\end{array}$ & $\begin{array}{l}932^{\circ} \mathrm{C} \text { (maximum } \\
\text { continuous) }\end{array}$ & $900^{\circ} \mathrm{C}$ & $\begin{array}{l}932^{\circ} \mathrm{C} \text { (maximum } \\
\text { continuous) }\end{array}$ & $900^{\circ} \mathrm{C}$ \\
\hline $\begin{array}{l}\text { Time needed for reaching the altitude of } 20000 \mathrm{ft} \\
(6096 \mathrm{~m}) / \text { czas potrzebny do wejścia na wysokość } \\
20000 \mathrm{ft}(6096 \mathrm{~m})\end{array}$ & $16 \mathrm{~min}$ & $17 \mathrm{~min}$ & $35 \mathrm{~min}$ & $44 \min 30 \mathrm{~s}$ \\
\hline $\begin{array}{l}\text { Distance needed for reaching the altitude of } 20000 \mathrm{ft} \\
(6096 \mathrm{~m}) / \text { droga potrzebna do wejścia na wysokość } \\
20000 \mathrm{ft}(6096 \mathrm{~m})\end{array}$ & $49 \mathrm{NM}(91 \mathrm{~km})^{8)}$ & $57 \mathrm{NM}(106 \mathrm{~km})$ & $55 \mathrm{NM}(102 \mathrm{~km})$ & $60 \mathrm{NM}(111 \mathrm{~km})$ \\
\hline
\end{tabular}

the vicinity of Bagram is located at the altitude of $10500 \mathrm{ft}$ (3200 m) and additionally a safety margin has to be added for possible mobile anti aircraft missile station activities. Hence, for the calculations the cruising altitude was assumed $20000 \mathrm{ft}(6096 \mathrm{~m})$. Then the authors calculated the time and distance needed to climb to that altitude at the parameters TIT $932^{\circ} \mathrm{C}$ and TIT $900^{\circ} \mathrm{C}$ in the summertime and wintertime. The temperatures are indicated by the manufacturers as the most efficient while climbing.
Wojskowego w Afganistanie. Najwyższe przewyższenie w okolicach Bagram usytuowane jest na wysokości $10500 \mathrm{ft}$ (3200 m), dodatkowo należy dodać do tego bezpieczną wysokość jako zapas gwarantujący przelot nad wierzchołkami i ewentualne uniknięcie zagrożenia ze strony przenośnych zestawów służących do zwalczania statków powietrznych. W związku z powyższym, do kolejnych obliczeń wzięto pod uwagę poziom lotu równy $20000 \mathrm{ft}$ (6096 m), obliczając jak długo samolot będzie się wznosił na zadaną wysokość oraz

Table 5. Calculated aircraft service ceiling) (C-130E) under different ambient conditions and different airfields [7]

Tabela 5. Obliczony pułap praktyczny lotu ${ }^{9}$ samolotu C-130E w różnych warunkach atmosferycznych i różnych lotnisk [7]

\begin{tabular}{|c|c|c|c|c|}
\hline $\begin{array}{l}\text { Ambient conditions/ } \\
\text { uwarunkowania }\end{array}$ & Powidz & Bagram & Powidz & Bagram \\
\hline Temperature/temperatura & $20^{\circ} \mathrm{C}$ & $38^{\circ} \mathrm{C}$ & $-6^{\circ} \mathrm{C}$ & $0^{\circ} \mathrm{C}$ \\
\hline $\begin{array}{c}\text { Assumed TIT/ } \\
\text { założone TIT lotu }\end{array}$ & \multicolumn{4}{|c|}{$932^{\circ} \mathrm{C}$ (maximum continuous) } \\
\hline $\begin{array}{l}\text { Aircraft mass/ } \\
\text { masa samolotu }\end{array}$ & \multicolumn{4}{|c|}{155000 pounds $(70306 \mathrm{~kg})$} \\
\hline $\begin{array}{c}\text { Calculated aircraft service } \\
\text { ceiling/obliczony putap } \\
\text { praktyczny lotu }\end{array}$ & $13500 \mathrm{ft}(4115 \mathrm{~m})$ & $9000 \mathrm{ft}(2743 \mathrm{~m})$ & $18200 \mathrm{ft}(5547 \mathrm{~m})$ & $17500 \mathrm{ft}(5334 \mathrm{~m})$ \\
\hline
\end{tabular}

The synthesis of the results of the comparison shows that the increase of TIT by $32^{\circ} \mathrm{C}$ at each of the four C-130 engines reduces the climb time to the altitude of $20000 \mathrm{ft}(6096 \mathrm{~m})$ by 9 minutes on average at the ambient temperature of $38^{\circ} \mathrm{C}$

\footnotetext{
8) $1 \mathrm{~km}=0.53961 \mathrm{NM}$

9) Service ceiling is an altitude at which the highest climb rate is $0.5 \mathrm{~m} / \mathrm{s}$ [6]
}

jaką drogę przebędzie, używając parametrów TIT $932^{\circ} \mathrm{C}$ oraz $900^{\circ} \mathrm{C}$ latem i zimą. Wskazane temperatury producent silników sugeruje jako najbardziej efektywne podczas wznoszenia samolotu.

\footnotetext{
8) $1 \mathrm{~km}=0,53961 \mathrm{NM}$

9) Pułap praktyczny jest to wysokość, na której największa prędkość pionowego wznoszenia wynosi $0,5 \mathrm{~m} / \mathrm{s}$ [6]
} 
and reduces the distance by approximately $8 \mathrm{NM}(14.5 \mathrm{~km})$ at the temperature of $0^{\circ} \mathrm{C}$. Additionally, the fuel consumption calculations (fuel needed to reach the altitude) should be verified so that the crew can make a decision regarding the power needed to reach the altitude in relation to the selected flight trajectory. The above parameter is significant when choosing the climb profile, including the flight over the mountain areas and possible reaction of the mobile anti aircraft missile stations.

Another analysis was made focusing on the cruise and determining of the maximum altitude for the same TIT $932^{\circ} \mathrm{C}$ and different aircraft mass during a flight in the summer and wintertime.

The above analyses indicate the necessity to perform a flight simulation before its actual realization considering the key atmospheric factors in order to carry out the assumed transport task. The maximum takeoff mass is a serious problem for the crew if the flight has to be carried out in the summer at high ambient temperatures. The above examples (the first one in particular) for which the temperature reaches $38^{\circ} \mathrm{C}$ undermine the realizability of the flight from the Bagram airfield where the mountains in the radius of 15 NM $(24 \mathrm{~km})$ reach the elevation of $10500 \mathrm{ft}(3200 \mathrm{~m})$ and higher. In such a situation the crew has to reduce the aircraft mass (mass of fuel or cargo). From the operational point of view the realization of the above could be difficult due to the necessity to transport a given cargo mass or lack of possibility to refuel on the way to the destination.

Considering the last stage of the flight, the authors focused mainly on the distance covered during the approach to landing until a complete halt. During the final approach the plane maintains the $3^{\circ}$ descent angle. The variables are: the temperature and the elevation of the airfields on which the plane lands at its mass of 155000 pounds $(70306 \mathrm{~kg})$.

The synthesis of the resulst shown in table 6 shows how
Synteza wyników porównania obrazuje, że zwiększenie TIT o $32^{\circ} \mathrm{C}$ na każdym z czterech silników samolotu C-130 zmniejsza średnio czas wznoszenia na zadaną wysokość $20000 \mathrm{ft}$ (6096 m) o około 9 min przy temperaturze powietrza $38^{\circ} \mathrm{C}$ i skraca drogę o około $8 \mathrm{NM}(14,5 \mathrm{~km})$ przy temperaturze $0^{\circ} \mathrm{C}$. Dodatkowo należy sprawdzić obliczenia związane z ilością zużytego paliwa na wznoszenie do żądanej wysokości tak, aby załoga mogła podjąć prawidłową decyzję, jaką moc użyć podczas wznoszenia w stosunku do wybranej trasy lotu, potrzebnej na uzyskanie odpowiedniej wysokości lotu. Powyższy parametr ma istotne znaczenie przy wyborze profilu wznoszenia podczas odlotu z lotniska startu, z uwzględnieniem bezpiecznego przelotu nad pasmem górskim i ewentualnym oddziaływaniem przenośnych, naziemnych zestawów obrony przeciwlotniczej.

Kolejnej analizy dokonano, skupiając uwagę na przelocie i określeniu maksymalnej wysokości dla jednakowej temperatury TIT $932^{\circ} \mathrm{C}, \mathrm{z}$ różnymi masami samolotu $\mathrm{w}$ trakcie lotu zimą i latem.

Powyższe analizy wskazują na konieczność przeprowadzenia symulacji lotu przed jego rzeczywistą realizacją, z uwzględnieniem kluczowych czynników atmosferycznych, celem wykonania założonego zadania transportowego. Maksymalna masa do startu stanowi poważny problem dla załogi w sytuacji konieczności wykonania lotu latem przy wysokich temperaturach. Powyższe przykłady (a w szczególności pierwszy), gdzie temperatura wynosi $38^{\circ} \mathrm{C}$ poddaje pod wątpliwość możliwość wykonania przelotu $\mathrm{z}$ lotniska w Bagram, gdzie góry w promieniu 15 NM (24 km) sięgają wysokości równej 10500 ft (3200 m) i wyższej. W tej sytuacji załoga musi koniecznie obniżyć masę samolotu przez zmniejszenie ilości paliwa, bądź masy towaru. Z operacyjnego punktu widzenia zrealizowanie tego wniosku może być niejednokrotnie bardzo trudne do wykonania, ze względu na konieczność przewozu określonej masy towaru

Table 6. Distance covered to a complete halt of the C-130E aircraft counted from the altitude of $50 \mathrm{ft}$ [7]

Tabela 6. Dystans do całkowitego zatrzymania samolotu C-130E z wysokości 50 ft [7]

\begin{tabular}{|c|c|c|c|c|}
\hline $\begin{array}{l}\text { Ambient conditions/ } \\
\text { uwarunkowania }\end{array}$ & \multicolumn{2}{|c|}{ Powidz } & \multicolumn{2}{|c|}{ Bagram } \\
\hline Temperature/temperatura & $20^{\circ} \mathrm{C}$ & $-6^{\circ} \mathrm{C}$ & $38^{\circ} \mathrm{C}$ & $0^{\circ} \mathrm{C}$ \\
\hline $\begin{array}{l}\text { Airfield elevation/ } \\
\text { wysokość lotniska }\end{array}$ & \multicolumn{2}{|c|}{$381 \mathrm{ft}(116 \mathrm{~m})$} & \multicolumn{2}{|c|}{$4265 \mathrm{ft}(1300 \mathrm{~m})$} \\
\hline $\begin{array}{l}\text { Aircraft Anti-slip system/ } \\
\text { uktad antypoślizgowy }\end{array}$ & \multicolumn{4}{|c|}{ On/pracuje } \\
\hline $\begin{array}{c}4 \text { engines on - reverse } \\
\text { thrust/4 silniki pracujace- } \\
\text { ciag wsteczny }\end{array}$ & \multicolumn{4}{|c|}{ Used when kraking/użyty podczas hamowania } \\
\hline $\begin{array}{l}\text { Wind at landing/sita wiatru } \\
\text { do lądowania }\end{array}$ & \multicolumn{4}{|c|}{$0 \mathrm{~km} / \mathrm{h}$} \\
\hline Braking/hamowanie & \multicolumn{4}{|c|}{ Good/dobre } \\
\hline $\begin{array}{l}\text { Landing flaps/klapy do } \\
\text { lądowania }\end{array}$ & \multicolumn{4}{|c|}{$100 \%$} \\
\hline $\begin{array}{l}\text { Distance to a complete } \\
\text { halt from the altitude of } \\
50 \mathrm{ft}(15 \mathrm{~m}) / \text { dystans do } \\
\text { calkowitego zatrzymania z } \\
\text { wys. } 50 \mathrm{ft}(15 \mathrm{~m})\end{array}$ & $4500 \mathrm{ft}(1371 \mathrm{~m})$ & $4200 \mathrm{ft}(1280 \mathrm{~m})$ & $5400 \mathrm{ft}(1645 \mathrm{~m})$ & $4850 \mathrm{ft}(1478 \mathrm{~m})$ \\
\hline
\end{tabular}


important the temperature and the airfield elevation above the sea level are for the plane to stop. In the extreme case, i.e. at the temperature of $38^{\circ} \mathrm{C}$ and the airfield elevation of $4265 \mathrm{ft}(1300 \mathrm{~m})$ in Bagram the distance until the complete halt is longer by $1300 \mathrm{ft}(396 \mathrm{~m})$ as compared to the distance the aircraft would cover in the wintertime in Powidz.

\section{Conclusions}

In this paper the influence of only some elements on the flight characteristics and the operating parameters has been taken into account. The introduction of additional factors into the analysis such as: the resistance coefficient, wind, runway tilt and the type of tarmac would require hours of painstaking calculations or the application of computer assisted simulation techniques.

These elements have been omitted on purpose in order to shift focus onto the importance of the ambient temperature and elevation of the airfield of takeoff or landing in military transportation. The paper also showed what altitude the aircraft can reach with a given mass that at the same time might constitute the task realizability limit. It is certain that further research should be expanded by the factors omitted herein. Additionally, attention should be focused on a detailed analysis of the atmospheric conditions during the flight from Poland to Afghanistan as a separate subject of investigations. Finally, due to lack of a flight profile simulation system it seems necessary to develop software for the C-130 aircraft, thus optimizing the settings of the engine parameters for the most efficient engine operation. Having such software would serve as a profile planner and simulator particularly in terms of optimum fuel consumption and cargo mass for a given mission under variable ambient conditions.

Paper reviewed/Artykut recenzowany

\section{Bibliography/Bibliografia}

[1] CSTO PL1C-130E(H)-1 Flight Manual PLAF Series C-130E Aircraft.

[2] www.matca.gov.af/airports/bagram.htm.

[3] www.mapsofworld.com/afghanistan/weather-in-afghanistan. html.

[4] AIP Polska AD 2 EPPW-1.

[5] pl.wikipedia.org/wiki/Geografia_Polski.

[6] Ilustrowany leksykon lotniczy Technika Lotnicza. Warszawa, WKE, 1988.

[7] Technical Order 1C-130E(H)-1-1.

Mr. Michał Erdmański - Air Transportation Base.

Michat Erdmański - 3. Skrzydto Lotnictwa Transportowego.

e-mail: erdmanski@wp.pl lub braku możliwości lądowania i uzupełnienia ponownie paliwa w drodze do punktu docelowego.

Rozważając ostatni etap lotu, skupiono uwagę głównie na odległości samolotu jaką przebędzie podczas podejścia do lądowania i lądowania do chwili całkowitego zatrzymania. W trakcie końcowego podejścia samolot będzie utrzymywał $3^{\circ}$ ścieżkę schodzenia. Zmiennymi są: temperatura oraz wysokości lotnisk, na których samolot będzie lądował przy masie wynoszącej 155000 funtów $(70306 \mathrm{~kg})$.

Synteza wyników zamieszczonych w tablicy 6 uwidocznia, jak wielkie znaczenie do zatrzymania samolotu mają temperatura oraz wysokość lotniska nad poziomem morza.

W skrajnym przypadku, tj. przy temperaturze $38^{\circ} \mathrm{C}$ i wysokości lotniska $4265 \mathrm{ft}(1300 \mathrm{~m})$ w Bagram droga do całkowitego zatrzymania jest dłuższa o $1300 \mathrm{ft}(396 \mathrm{~m}) \mathrm{w}$ porównaniu do drogi, jaką przebyłby samolot lądujący zimą w Powidzu.

\section{Podsumowanie}

W niniejszej pracy wzięto pod uwagę tylko wpływ niektórych elementów na charakterystykę lotu oraz parametry pracy i osiągi samolotu. Wprowadzenie do analiz dodatkowych czynników, takich jak: współczynnik oporu, siła wiatru, nachylenie drogi startowej i rodzaj nawierzchni wymagałoby wielogodzinnych żmudnych obliczeń lub zastosowania komputerowo wspomaganych technik symulacyjnych.

Elementy te ominięto celowo, aby ukazać jak ważne znaczenie w lotnictwie transportowym mają temperatura oraz wysokość lotniska z którego, bądź na które statek powietrzny musi wykonać operacje startu lub lądowania. Przedstawiono również, na jaką wysokość może się wznieść samolot z odpowiednią masą, stanowiącą niejednokrotnie granicę możliwości wykonania zadania. Niewątpliwie dalsze kierunki badań należy poszerzyć o czynniki pominięte w niniejszej pracy. Dodatkowo należy skupić uwagę na dokładnej analizie warunków atmosferycznych, mogących wystąpić podczas przelotu z Polski do Afganistanu, jako osobnego przedmiotu badań. Ostatecznie, ze względu na brak systemu symulowania profilu lotu, wydaje się być koniecznym stworzenie programu komputerowego dla samolotu C-130 i poprzez to zoptymalizowanie parametrów ustawienia pracy silnika dla najefektywniejszego ich wykorzystania. Posiadanie takiego programu, służyłoby do zaplanowania profilu lotu oraz symulacji ze szczególnym uwzględnieniem optymalnej ilości paliwa oraz towaru, dla danej misji w zmiennych warunkach atmosferycznych.

Mr. Krzysztof Szymaniec - Air Transportation Wing.

Krzysztof Szymaniec - 33. Baza Lotnictwa Transportowego.

e-mail:szymaniec@op.pl 